\title{
Labour market effects of job displacement for prime-age and older workers
}

\author{
Anja Deelen* (1), Marloes de Graaf-Zijl and Wiljan van den Berge
}

*Correspondence:

A.P.Deelen@cpb.nl

CPB Netherlands Bureau for Economic Policy Analysis, P.O. Box 80510,2508 GM, The Hague, The Netherlands

\begin{abstract}
This paper studies the effects of firm closures associated with bankruptcies on the employment status and wages of prime-age and older workers using Dutch administrative data for the period 2000-2011. Applying difference-in-differences techniques and non-parametric matching, we find adverse effects on the probability to be in work and on wages earned in the new job, which are larger for older workers than for prime-age workers. Within the older-age group, the effects are stronger for formerly long-tenured workers, for older workers who lost their job in declining sectors in the regional labour market and for workers who changed sectors. In the prime-age group, these differences are less pronounced. Our results suggest that job- and sector-specific factors are important for understanding the more vulnerable position of older workers after job loss.
\end{abstract}

JEL Classification: J14, J63, J65

Keywords: Firm closures, Older workers, Unemployment

\section{Introduction}

Displacement may pile the burden of economic adjustments on an unfortunate minority of workers. Especially for older workers, finding new employment after displacement appears to be a challenge. The labour market position of older displaced workers is of specific interest due to the ageing population and the ensuing policy targets to keep older workers in the work force. This paper investigates to what extent the impact of firm closures associated with bankruptcy differs between older and prime-age workers and studies how long tenure in the previous job, finding work in a different industry than the one from which they lost their previous job and the local labour market conditions in the industry from which workers are displaced correlated with these differences.

There are several reasons for a stronger displacement effect among older workers. On the demand side, older workers may be less attractive to new employers due to a relatively high-wage costs-to-productivity ratio for older workers. This higher ratio may be the result of deferred compensation schemes (Lazear 1981; Daniel and Heywood 2007; Heywood et al. 2010) and of a strong bargaining position of wellprotected older workers that are well-represented by labour unions who negotiate costly special provisions for older workers in collective bargaining schemes (De Hek and Van Vuuren 2011). On the supply side, older workers generally have higher reservation wages due to longer benefit entitlements (Van Ours and Vodopivec 2006) or

(c) The Author(s). 2018 Open Access This article is distributed under the terms of the Creative Commons Attribution 4.0 International License (http://creativecommons.org/licenses/by/4.0/), which permits unrestricted use, distribution, and reproduction in any medium, provided you give appropriate credit to the original author(s) and the source, provide a link to the Creative Commons license, and indicate if changes were made. 
better options to retire from the labour market (Ichino et al. 2013), sometimes with generous early retirement schemes. In addition, many older workers embody substantial firm-specific human capital, which is forgone when they are displaced (Poletaev and Robinson 2008); sector-specific capital which is lost upon displacement if the worker cannot find new employment in the same sector (Carrington 1993; Neal 1995); or task-specific human capital (Gibbons and Waldman 2004) that is lost if a worker needs to change occupation. Many older workers end up in shrinking occupations (Autor and Dorn 2009; Bosch and ter Weel 2013), which increases the probability that they will need to find a new job in another occupation.

Earlier research has established a substantial and persistent effect of displacement on labour market success. Especially in the USA, researchers have been interested in this phenomenon for decades ${ }^{1}$. They have shown a severe and permanent drop in earnings after displacement. The European literature on displacement is more recent and focuses more on the incidence of (un)employment instead of just on earnings or wages ${ }^{2}$. In general, the US literature has found that losses are primarily caused by lower wages in post-displacement jobs, whereas evidence from many European countries finds almost no wage losses for those who re-enter employment, but find significantly lower employment probabilities instead (Hijzen et al. 2010). Differences between age groups are found both in the USA and in Europe ${ }^{3}$. Some studies explore the relation between labour market success after displacement and long tenure in the previous job (Hijzen et al. (2010), Kuhn (2002)) or changing industry (Burda and Mertens (2001), Huttunen et al. (2011)), but they do not analyse how these correlations differ between age groups.

For the Dutch case, Fouarge et al. (2010) followed individuals who were displaced in 2005 for 12 months after their dismissal and found that displacement due to plant closures led to $7 \%$ lower wages, whereas individual dismissal led to $13 \%$ lower wages. Surprisingly, they found no additional wage effect of changing industry after dismissal. For their study, Fouarge et al. (2010) used the same administrative data as we use in this paper. In an earlier comparative study for the USA and the Netherlands, Gautier et al. (2002) found little evidence for adverse wage effects based on survey information. Using the same survey data, Mooi-Reci and Ganzeboom (2015) found a significant scarring effect of unemployment in general in the period 1985-2000, with a notable disparity in the unemployment scarring by gender. All three Dutch studies have asked for further analysis on the effects of displacement in the Netherlands to get a better grasp of its actual effects.

Our study adds a new perspective to the literature by analysing three factors that vary within and between age groups: job tenure, working in weak labour markets and switching industries. Using the difference-in-differences techniques that have been the standard in the literature since the seminal work of Jacobsen et al. (1993), we determine the effect of firm bankruptcies on employment participation and wages of the workers involved. We improve on this method by estimating heterogeneous treatment effects within this difference-in-differences approach, which allows us to determine to what extent there are differences within age groups and analyse how these differences vary between age groups.

Our strategy is to apply a difference-in-differences approach combined with nonparametric matchings. We use extensive administrative linked employer-employee data for the Netherlands that include all workers, in combination with data on firm bankruptcies that are drawn from an administrative source as well. We take a sample of workers who were displaced due to firm bankruptcies in the period 2000-2009 and follow them 
up to 2011. The size of our dataset allows us to construct a control group of non-displaced workers using non-parametric matching techniques, following Ichino et al. (2013). In doing so, we reduce the potential bias that might result from the selection of the controls (Hijzen et al. 2010; Huttunen et al. 2011), since the treated and controls have the exact same observable characteristics. In total, we have nearly 19,000 treated and 50,000 controls in the age-group 35-54 years old. We test for heterogeneous treatment effects by expanding the standard difference-in-differences specification.

Our results indicate that the labour market outcomes after displacement are highly contingent on age, especially in terms of employment probabilities. Within the older-age group, the outcomes are related to job tenure in the former job, the local labour market situation in the sector from which people are displaced and whether people find work in another sector. For prime-age workers, tenure in the job before displacement makes less of a difference for their outcomes after displacement than it does for older workers. Likewise, older displaced workers are more sensitive to the situation in the local labour market in the industry from which they are displaced and experience stronger negative effects of changing industries after displacement on their post-displacement wages, probably due to industry-specific human capital that is lost upon displacement. These results suggest that job- and sector-specific factors are important for understanding the more vulnerable position of older workers after job loss.

The paper is organized as follows. Section 2 shows how we constructed the data from various administrative data sources, displays descriptive graphs and presents our empirical strategy. Section 3 discusses the results of our analyses, and Section 4 presents sensitivity analyses. Section 5 concludes.

\section{Data and empirical strategy}

\subsection{Data}

This paper uses administrative linked employer-employee data in which all jobs of all Dutch citizens can be followed over time from 1999 until 2011. This so-called Social Statistical File (SSB) includes information on the exact start and end date of jobs and the wages earned in those jobs. We merged these data with information on personal characteristics from municipal registrations (GBA) and data on jobs involved in firm bankruptcies in the period 2000-2009. From these data, we formed a treatment group of workers who were involved in firm closures associated with bankruptcies at some point in time between 2000 and 2009 and a control group of workers who were not displaced due to firm bankruptcies within the first 12 months after the displacement date ${ }^{4}$ of the worker they are matched to. Sections 2.2 and 2.3 provide more information about the selection of treatment and control group.

Employment is defined as having positive wage information, or positive income from self-employment, in our monthly earnings records. This implies that the individual worked at least $1 \mathrm{~h}$ in the private or public sector, or as a self-employed worker, in that month. We do not distinguish between employment as dependent employee or as selfemployed worker. Nor do we distinguish between unemployment and inactivity, because we do not have information about the individual's job search behaviour.

The data contain yearly information on the wages earned in a specific job. From this information, we constructed monthly real gross wages by combining this year's wage information with the start and end date of the job. Many earlier studies used quarterly 
earnings that were sensitive to the number of weeks that a person worked during that quarter. Finding new employment during a quarter impacted earnings in those studies, and the displaced group was impacted by this more than the control group of nondisplaced workers, inducing a bias. According to Topel (1990), virtually all of the short-run recovery of annual earnings is due to an increase in weeks worked, rather than to increases in weekly earnings. In this paper, we disentangle the employment probability from the wages earned. In order to do so, we use monthly wages, corrected for the number of days that a person actually worked in the specific month. This implies that our wage measure is not sensitive to people finding new employment during the month. The wage measure that we actually use is the monthly real gross wage relative to the wage 13 months ${ }^{5}$ before the displacement, since this presentation facilitates the interpretation of the estimation coefficients. We choose the 13th month before displacement because this is before the common dip in the months leading up to displacement that was first established by Jacobsen et al. (1993).

\subsection{The treatment group}

Our treatment group consists of workers between 35 and 54 years of age who were involved in firm closures associated with bankruptcies at some point in time between 2000 and 2009. We include all workers who exited the firm during the year their firm went bankrupt or during the year before ${ }^{6}$. The reason for doing so lies in the potential selectivity bias that may result when workers possess private information about an impending displacement (Burda and Mertens 2001). If the bankruptcy is anticipated, workers with the best outside options might leave the ship before it sinks and one may end up with a selective sample of workers. Therefore, it is common to include all workers who exited the firm up to 1 year, and in some studies even 2 years, before bankruptcy is displaced. Taking a wider window mitigates the problem of early leavers but increases the risk that workers are included who moved for reasons other than firm closure. Dustmann and Meghir (2005) and Eliason and Storrie (2006) tested the effect of using a 2-year time window. According to Dustmann and Meghir (2005), the wider window led to weaker results, but the difference is insignificant, while Eliason and Storrie find that the wider window led to stronger results. Our dataset treats all employment separations (both dismissals and employee-initiated separations) at firms where the court has issued a bankruptcy in year $t$ or year $t+1$ as displaced. We have empirically defined the displacement date at the time of the separation rather than the date of the bankruptcy.

We do not restrict our sample to long-tenured workers, to workers in large firms, to men or to a certain sector of industry, like some other studies. Instead, we include the broad array of workers who were hit by firm bankruptcies and estimate the differences between these various groups of workers. The seminal work of Jacobsen et al. (1993) found strong effects of job displacement that may to a substantial part be attributed to their focus on long-tenured workers: it led to more negative results than one would find for the full sample of workers that were hit by mass layoffs and firm closures (Hijzen et al. 2010). We therefore include both long- and short-tenured workers in our treatment group and later estimate the differences in the outcomes between both groups. Other common restrictions on the sample of displaced workers are to exclude workers from small firms, focus on men or on a certain sector and restrict to prime-age workers (e.g. 20-49 is a common restriction). Our sample includes men and women from all industries and all ages ${ }^{7}$ 
and focuses on the differences between age groups. We choose to exclude workers older than 55 to be certain that our results for the older-age group are not impacted by early retirement or other ways to leave the labour market ${ }^{8}$. An alternative retirement channel for older workers is inflow into disability insurance. However, the inflow into disability insurance has plummeted in recent decades due to policy reforms ${ }^{9}$. Finally, we exclude workers younger than 35 because they typically include a large share of people who are still in education and are employed in small part-time jobs on the side.

\subsection{The control group}

Our control group was taken from the same dataset as the treatment group. To create our potential control group, we selected workers who were in work during the entire month in which the bankruptcy occurred in which a person from the treatment group was involved. Our control group was not restricted to the people who remained employed in the months after the treated were displaced. Hijzen et al. (2010) and Huttunen et al. (2011) have shown that such a restriction on the control group leads to an upward bias in the results. The only restrictions that we used when we created our potential control group is that they were in employment the entire month during which a treated person was displaced and that controls are not displaced due to firm bankruptcies within the first 12 months after the displacement date of the worker they are matched to ${ }^{10}$. Besides this restriction, both displaced and controls are subject to the same labour market risks, such as dismissals on individuals grounds, mass layoffs and future firm closures, voluntary quits or job mobility. Quintin and Stevens (2005) and Huynh et al. (2017) have shown that industry shutdown rates may negatively impact workers experiencing a layoff at continuing firms. Industry level stress flows down to firms and workers within the industry, which may lead to controls being affected by the displacement of the treated. This may result in an underestimation of the actual effect.

Following Ichino et al. (2013), we apply a procedure of non-parametric matching to find matches for the displaced workers with exactly the same observed characteristics ${ }^{11}$. Matching variables are age in years, sex, industry, education level, working hours, region and tenure class ${ }^{12}$. For each displaced worker, a maximum of 5 exactly matching controls was drawn from the data. In principle, a control person can serve as control for more than one displaced person, but given the large number of potential controls relative to the number of treated, the probability that one person appears more than once as a control is very small.

\subsection{Descriptive statistics}

Table 1 presents descriptive statistics of the pre- and post-matching samples of the treated and controls for the year 2005. Out of about 9,000 workers aged 35 to 54 displaced in 2005, we have been able to find one or more matching controls for more than 1500 'treated' workers. For these 1500 workers that were involved in a firm bankruptcy, a control group of more than 4000 non-displaced workers was drawn from the entire population of nearly 5.5 million $^{13}$. In total for all years we observe displaced workers due to firm bankruptcies, we have 18,663 observations of matched treated and 49,827 observations of matched controls between 35 and 54 years of age, leaving us with an average of 2.7 controls per treated.

Before the matching procedure, the potential control group differed markedly from the treatment group in terms of age, sex, sector of industry and other characteristics. After the 
Table 1 Summary statistics

\begin{tabular}{|c|c|c|c|c|}
\hline & \multicolumn{2}{|c|}{ Pre-matching } & \multicolumn{2}{|c|}{ Post-matching } \\
\hline & Treated & Controls & Treated & Controls \\
\hline Monthly wage (euros) & 2764.73 & 2844.40 & 3120.55 & 3743.27 \\
\hline (std. dev.) & 1578.74 & 6497.72 & 1767.68 & 2787.01 \\
\hline Tenure (years) & 6.61 & 9.35 & 6.78 & 7.16 \\
\hline (std. dev.) & 6.44 & 7.88 & 5.96 & 5.45 \\
\hline Age & 43.02 & 43.91 & 41.85 & 40.89 \\
\hline (std. dev.) & 5.67 & 5.65 & 5.62 & 5.57 \\
\hline \multicolumn{5}{|l|}{ Education } \\
\hline Low & .14 & .09 & .06 & .03 \\
\hline Middle & .66 & .54 & .70 & .63 \\
\hline High & .21 & .37 & .24 & .35 \\
\hline Female & .27 & .40 & .21 & .15 \\
\hline Part-time & .27 & .39 & .20 & .15 \\
\hline Permanent contract & .96 & .97 & .97 & .97 \\
\hline \multicolumn{5}{|l|}{ Position } \\
\hline Director and major shareholder & .04 & .03 & .02 & .02 \\
\hline Temporary agency worker & .03 & .02 & .03 & .03 \\
\hline On-call employee & .01 & .01 & .00 & .00 \\
\hline Other & .93 & .92 & .94 & .96 \\
\hline \multicolumn{5}{|l|}{ Sector of industry } \\
\hline Manufacturing & .25 & .15 & .26 & .25 \\
\hline Wholesale and retail trade & .13 & .11 & .09 & .06 \\
\hline Transport and storage & .08 & .06 & .04 & .02 \\
\hline Accommodation and food serving & .01 & .02 & .00 & .00 \\
\hline Information and communication & .00 & .01 & .00 & .00 \\
\hline Financial institutions & .12 & .03 & .14 & .22 \\
\hline Consultancy, research & .12 & .10 & .14 & .15 \\
\hline Renting and leasing of tangible goods & .05 & .05 & .04 & .03 \\
\hline Public administration & .00 & .10 & .00 & .00 \\
\hline Education & .00 & .08 & .01 & .01 \\
\hline Health and social activities & .04 & .16 & .05 & .06 \\
\hline Culture, sport and recreation & .01 & .01 & .00 & .00 \\
\hline Other services & .02 & .01 & .02 & .01 \\
\hline Other & .16 & .12 & .21 & .20 \\
\hline Observations & 9195 & $37,347,346$ & 1553 & 4179 \\
\hline
\end{tabular}

Notes: The summary statistics refer to 2005. The table only includes workers between 35 and 54 years of age. Source: Own calculations using registration data from Statistics Netherlands on displaced workers

matching procedure these differences have vanished to a large extent. The sample of postmatching controls (column 4) resembles the sample of post-matching treated in terms of age, job positions and sectors of industry. For example, 97\% of the matched treated and controls work on a permanent contract and 3\% work for a temporary work agency. Regarding region of residence, there is no selection before or after matching (not in table).

Note that, although we applied non-parametric matching, the shares of the matched treated and the matched controls are close but not always exactly the same. The only reason that the shares diverge is because not all subgroups (male vs. female, part-time vs. full-time etc.) have the same number of controls. For example, in the case of sex, the divergence is caused by the fact that treated males are on average matched to more 
controls than treated females are. Hence, in case the shares for the matched controls are calculated as weighted averages, thus controlling for the number of controls per treated, the shares are equal to those for the matched treated, as do average tenure and age. Also, regarding wages, variation in the number of controls create a divergence between postmatching treated and controls: the relatively high wages have more controls than low wages. Weighted by the number of controls, the divergence is much smaller (the weighted mean wage for the matched controls is 3203 euro), but not exactly zero as we match on wage classes. However, differences in the absolute wage levels between treated and controls should not affect our estimates, as our outcome variable is the wage relative to the wage 13 months before displacement.

Descriptive statistics in Fig. 1 indicate that the employment probabilities after firm bankruptcies are clearly lower for older workers than for younger workers. The upper panel of Fig. 1 shows the change in the employment probabilities (in percentage points) over the period from 24 months before up to 72 months after the bankruptcy, relative to 13 months before the bankruptcy, for treated and controls in the two age groups. The employment probability in the period between 13 months before displacement up to displacement is 1 by definition, since we require that workers were employed the entire year up to displacement. Directly after firm bankruptcy, employment probabilities plummet by about 51 and 57 percentage points, respectively, for prime-age and older displaced workers. This means that close to half of those workers who lost their job in a bankruptcy were able to make a job-to-job transition. After the recovery period, the probability to be in employment remains about 22 percentage points below that prior to the bankruptcy for prime-age workers and about 28 percentage points for older workers. Although the older

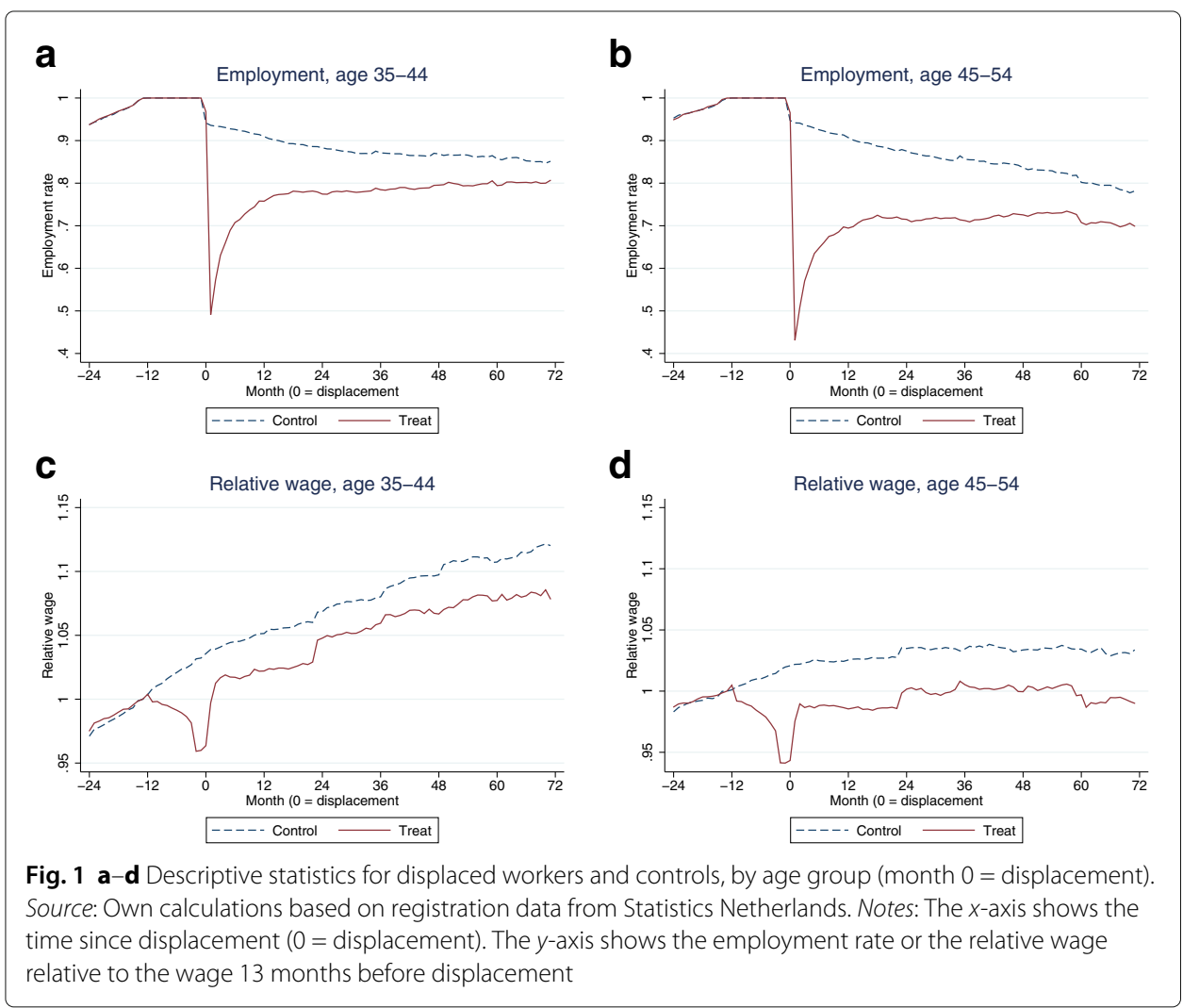


control group reduces its employment rate more strongly, the relatively large gap between the employment rate of the displaced and controls is persistent.

The lower panel of Fig. 1 shows the change (in percentage points) in the average wage over the period from 24 months before up to 72 months after firm bankruptcy, relative to the wage 13 months before displacement, for treated and controls in the two age groups. Wage profiles of controls are clearly steeper for prime-age workers than for older workers. In line with many other studies, we observe a wage dip before displacement ${ }^{14}$. The wage dip before displacement amounts to about 1 percentage points for both prime-age and older displaced workers. After displacement, wages of those in employment clearly recover over the course of the first year. For older workers, a relatively large wage gap between displaced and control groups results, which remains persistent in the longer run.

\subsection{Empirical strategy}

We use the difference-in-differences techniques that have been the standard in the literature since the seminal work of Jacobsen et al. (1993). We follow the recent literature and apply diff-in-diffs estimates to the matched sample (e.g. Couch and Placzek (2010); Eliason and Storrie (2006); Hijzen et al. (2010); Ichino et al. (2013)). This allows us to estimate the causal effect of job displacement ${ }^{15}$. While displacement due to firm bankruptcies is probably the most exogenous type of dismissal, we cannot exclude selection bias. Firms experiencing bankruptcies may differ from surviving firms, not only in firm characteristics but also in terms of employee characteristics. If confounding factors indeed influence both the probability to receive treatment and the potential outcomes of the treated, the estimated treatment effect is biased. By combining difference-in-differences techniques with matching, we reduce the bias in the estimated treatment effect by assuring that treated and controls have the same distributions of observable factors. Besides non-parametric matching, propensity score matching (PSM) is a commonly used matching method. An advantage of non-parametric matching is that treated and controls are matched on key variables of interest. A limitation is that increasing the number of matching variables to improve the similarity on observables between treated and controls induces that more observations are excluded because no match is available. If the excluded observations represent a specific population, this may lead to selection bias. With PSM, the treated are matched on a single propensity score representing the probability of receiving the treatment given the observed characteristics; if the number of potential confounding factors is large, PSM may have the advantage of excluding a lower number of treated from the sample. However, an important drawback of PSM is that, although matched pairs may have similar scores, they may differ in terms of observed variables of interest, introducing a bias in the results as well. It is not certain beforehand which method has the lowest bias. In this case, the size of the dataset allows us to apply non-parametric matching.

We start with a specification that follows Ichino et al. (2013) and focuses on two age groups of older versus prime-age workers. The basic model specification is

$Y_{i, t}=\sum_{d=-2}^{d=6} \alpha_{d} Z_{i} T_{i} D_{i, t}^{d}+\sum_{d=-2}^{d=6} \beta_{d} T_{i} D_{i, t}^{d}+\sum_{d=-2}^{d=6} \gamma_{d} Z_{i} D_{i, t}^{d}+\sum_{d=-2}^{d=6} \delta_{d} D_{i, t}^{d}+\eta_{i}+\theta_{t}+\epsilon_{i, t}$

where $Y_{i, t}$ is the outcome of interest (employment status or wage), $i$ is the individual worker, $t$ is the time measured in months, $Z_{i}$ is an indicator taking the value of 1 if a 
worker is aged $45-54$ and 0 if a worker is aged $35-44, T_{i}$ is a dummy taking 1 if the worker is displaced due to firm bankruptcy and $D_{i, t}^{d}$ is a dummy taking 1 for the record in which worker $i$ is observed at $d$ years distance from $(d=0)$, which is the (actual or fictional) date of displacement. $\eta_{i}$ is the unobserved individual fixed effect, $\theta_{t}$ captures calendar time effects (flexibly specified as a set of dummy variables for each calendar year) and $\epsilon_{i, t}$ is the individual and time-specific error term. We include 8-year dummies to flexibly estimate how the treatment effect evolves over time. Our base period is 2 years before the actual or fictional date of displacement. The effect of displacement for older workers compared to prime-age workers is represented by $\alpha_{d}$. To aid the interpretation, we present results as expected values of $Y_{i, t}$ for a given worker.

We expand upon the standard methodology in the literature by further exploring the treatment effects estimated with Eq. 1. We examine whether the different outcomes of older and prime-age workers after displacement are related to, for example, their tenure or industry by estimating heterogeneous treatment effects within the differencein-differences specification. For instance, older displaced workers may be more sensitive to longer job tenure, the local labour market situation in the sector of economic activity from which they are displaced ${ }^{16}$ or changing sectors. Note that these estimates cannot be interpreted as treatment effects, since there is not necessarily a common trend in the employment probabilities and wages of, for example, the long- and short-tenured workers. Rather, the estimates should be interpreted as an exploration of the reason behind the observed differences between older and prime-age workers in their labour market situation after displacement.

\section{Results}

In line with the literature on job displacement, our results from the difference-indifferences analysis on the matched sample indicate that both employment probabilities and wages plummet upon displacement and subsequently recover in the period thereafter (Table 2, Appendix). Although labour market outcomes of displaced workers improve over time, they do not reach the level of the counterfactual within our period of observation, neither for older nor for prime-age workers. The negative effects of displacement are persistent, at least up to 6 years after the firm closed down ${ }^{17}$.

Our results confirm that the effects of job displacement on employment probabilities are more negative for age group 45-54 (older workers) than for age group 35-44 (prime-age workers). Panel A of Table 2 shows the employment probabilities for both age groups from 1 year before up to 6 years after displacement. Compared to the control group, older workers (column 1) see their employment probabilities deteriorate by 28 percentage points immediately after displacement. For prime-age workers (column 2), this is 23 percentage points. The second year after displacement, the older-age group still has an employment rate about 18 percentage points lower than the control group, while displaced prime-age workers have a 12 percentage point lower employment rate; these figures decline over the remaining 4 years to 6 and 4 percentage points, respectively. The difference in treatment effects between displaced older and prime-age workers is over 5 percentage points in the first 2 years and comes down only gradually in subsequent years. The difference is statistically significant up to 6 years after displacement, confirming that older workers suffer stronger and longer-lasting effects from being displaced than prime-age workers. 
Table 2 Effects on the expected values of $Y_{i, t}$ for displaced older and prime-age workers and the difference between them

\begin{tabular}{|c|c|c|c|}
\hline & $\begin{array}{l}\text { Treatment effect older } \\
(45-54)\end{array}$ & $\begin{array}{l}\text { Treatment effect } \\
\text { prime-age (35-44) }\end{array}$ & $\begin{array}{l}\text { Difference between } \\
\text { older and prime-age }\end{array}$ \\
\hline \multicolumn{4}{|c|}{ Panel A: employment } \\
\hline \multirow[t]{2}{*}{ Year - 1} & $0.0110^{* * *}$ & $0.0062^{* * *}$ & $0.0048^{* * *}$ \\
\hline & $(0.0014)$ & $(0.0009)$ & $(0.0017)$ \\
\hline \multirow[t]{2}{*}{ Year 1} & $-0.2814^{* * *}$ & $-0.2292^{* * *}$ & $-0.0522^{* * *}$ \\
\hline & $(0.0014)$ & $(0.0010)$ & $(0.0017)$ \\
\hline \multirow[t]{2}{*}{ Year 2} & $-0.1757^{* * *}$ & $-0.1229^{* * *}$ & $-0.0529 * * *$ \\
\hline & $(0.0014)$ & $(0.0010)$ & $(0.0017)$ \\
\hline \multirow[t]{2}{*}{ Year 3} & $-0.1416^{* * *}$ & $-0.0986^{* * *}$ & $-0.0430 * * *$ \\
\hline & $(0.0016)$ & $(0.0011)$ & $(0.0019)$ \\
\hline \multirow[t]{2}{*}{ Year 4} & $-0.1088^{* * *}$ & $-0.0769^{* * *}$ & $-0.0320^{* * *}$ \\
\hline & $(0.0018)$ & $(0.0013)$ & $(0.0022)$ \\
\hline \multirow[t]{2}{*}{ Year 5} & $-0.0733^{* * *}$ & $-0.0602^{* * *}$ & $-0.0131^{* * *}$ \\
\hline & $(0.0019)$ & $(0.0013)$ & $(0.0023)$ \\
\hline \multirow[t]{2}{*}{ Year 6} & $-0.0569^{* * *}$ & $-0.0394^{* * *}$ & $-0.0176^{* * *}$ \\
\hline & $(0.0023)$ & $(0.0016)$ & $(0.0028)$ \\
\hline N & $4,657,804$ & $4,657,804$ & $4,657,804$ \\
\hline \multicolumn{4}{|c|}{ Panel B: relative wages } \\
\hline \multirow[t]{2}{*}{ Year -1} & $-0.0335^{* * *}$ & $-0.0268^{* * *}$ & $-0.0067^{* * *}$ \\
\hline & $(0.0009)$ & $(0.0006)$ & $(0.0010)$ \\
\hline \multirow[t]{2}{*}{ Year 1} & $-0.0552^{* * *}$ & $-0.0423^{* * *}$ & $-0.0128^{* * *}$ \\
\hline & $(0.0009)$ & $(0.0006)$ & $(0.0011)$ \\
\hline \multirow[t]{2}{*}{ Year 2} & $-0.0494^{* * *}$ & $-0.0345^{* * *}$ & $-0.0149 * * *$ \\
\hline & $(0.0009)$ & $(0.0006)$ & $(0.0011)$ \\
\hline \multirow[t]{2}{*}{ Year 3} & $-0.0450^{* * *}$ & $-0.0277^{* * *}$ & $-0.0172^{* * *}$ \\
\hline & $(0.0011)$ & $(0.0007)$ & $(0.0013)$ \\
\hline \multirow[t]{2}{*}{ Year 4} & $-0.0409^{* * *}$ & $-0.0273^{* * *}$ & $-0.0136^{* * *}$ \\
\hline & $(0.0012)$ & $(0.0008)$ & $(0.0015)$ \\
\hline \multirow[t]{2}{*}{ Year 5} & $-0.0329^{* * *}$ & $-0.0319^{* * *}$ & -0.0011 \\
\hline & $(0.0013)$ & $(0.0009)$ & $(0.0016)$ \\
\hline \multirow[t]{2}{*}{ Year 6} & $-0.0325^{* * *}$ & $-0.0332^{* * *}$ & 0.0007 \\
\hline & $(0.0016)$ & $(0.0011)$ & $(0.0020)$ \\
\hline N & $4,100,016$ & $4,100,016$ & $4,100,016$ \\
\hline
\end{tabular}

Notes: Calculations on the basis of fixed effects estimates of Eq. 1. Year -2 is the base year. Calculations for employment and wages are based on separate regressions. Full results are presented in the Appendix. Significance levels: ${ }^{*} 10 \%,{ }^{* *} 5 \%,{ }^{* * *} 1 \%$. Source: Own calculations using registration data from Statistics Netherlands on displaced workers

In terms of wages, older displaced workers are hit harder than prime-age displaced workers as well (panel B of Table 2). We focus on the real gross monthly wage (normalised by the level 13 months before displacement) of the treatment group compared to the control group. The year before displacement, anticipation effects are visible: wages of older and, to a lesser extent, of prime-age workers start to drop ${ }^{18}$. The reason is most likely that firms are typically in financial difficulty before bankruptcy is declared, leading to lower wage growth than otherwise would be the case.

Upon displacement older workers suffer almost 6 percentage points wage loss, while prime-age workers lose about 4 percentage points relative to the control group ${ }^{19}$. For prime-age workers, the negative impact declines to about 3 percentage points. For older workers, the negative impact gradually decreases to about 3 percentage points; hence, for both age groups, a persistent significance remains up to 6 years after displacement. Older 
workers' wages are hit harder during the first 4 years; in the next years, the difference is no longer statistically significant ${ }^{20}$.

The persistent gap between age groups might be related to the characteristics of the age groups. Due to longer job tenure, older workers may embody substantial firm-specific human capital, which is forgone when they are displaced (Poletaev and Robinson 2008). In addition, older workers may have built up industry-specific capital by a long work experience in a specific industry, and this is lost upon displacement if the worker cannot find new employment in the same industry (Carrington 1993; Neal 1995). Older workers may be especially vulnerable to this effect, since they are more likely to end up in shrinking occupations (Autor and Dorn 2009; Bosch and ter Weel 2013). Wages of older, long-tenured workers may also be relatively high due to deferred compensation schemes and because tenure-related elements in the employment protection legislation (i.e., severance payments, notice periods, lifo-rules) may strengthen their wage bargaining position.

Table 3 shows that older workers on average indeed have longer tenure than the primeage group. The difference in the share that was displaced from a declining labour market is small, and the share of workers that changes industry after displacement does not differ strongly between older and prime-aged workers.

But even if older workers would not have longer tenure, or were not displaced from declining labour markets more often, they might be affected strongly by these factors. This would for instance be the case if employers are more willing to invest in new firm- or industry-specific capital for prime-age workers than in older workers because they have more time to recoup their investment costs.

To provide more insight into the reasons behind the persistent gap between the age groups, the heterogeneous treatment effect in our difference-in-differences estimation tests to what extent job tenure and sector characteristics affect older worker's employment probabilities and wages after displacement in comparison to prime-age workers. From now on, we refer to this as older workers' 'sensitivity' to these characteristics. More specifically, we examine whether older workers are more sensitive to long job tenure, to the local labour market situation in the industry from which they are displaced and to making a transition to another industry.

Table 4 presents the effects on the expected values of $Y_{i, t}$ for displaced older and primeage workers with different characteristics. It compares workers with long and shorter tenure (with a cut-off at 7 years) ${ }^{21}$, workers in a declining local labour market with those in a growing local labour market and workers who find a job in a different (two-digit) sector after displacement with those who do not ${ }^{22}$.

Older workers are impacted more severely by displacement if they had a long tenure in their previous job. Column 1 shows that the employment probability of displaced older workers with long tenures is especially low in the first year after displacement:

Table 3 Characteristics of older and prime-age workers in the treatment group

\begin{tabular}{lll}
\hline & Older (45-54) & Prime-age (35-44) \\
\hline Long tenure ( $\geq 7$ years) & 0.28 & 0.13 \\
Declining sectoral-regional labour market & 0.65 & 0.64 \\
Changing sectors & 0.30 & 0.35 \\
\hline
\end{tabular}

Source: Own calculations using registration data from Statistics Netherlands on displaced workers 


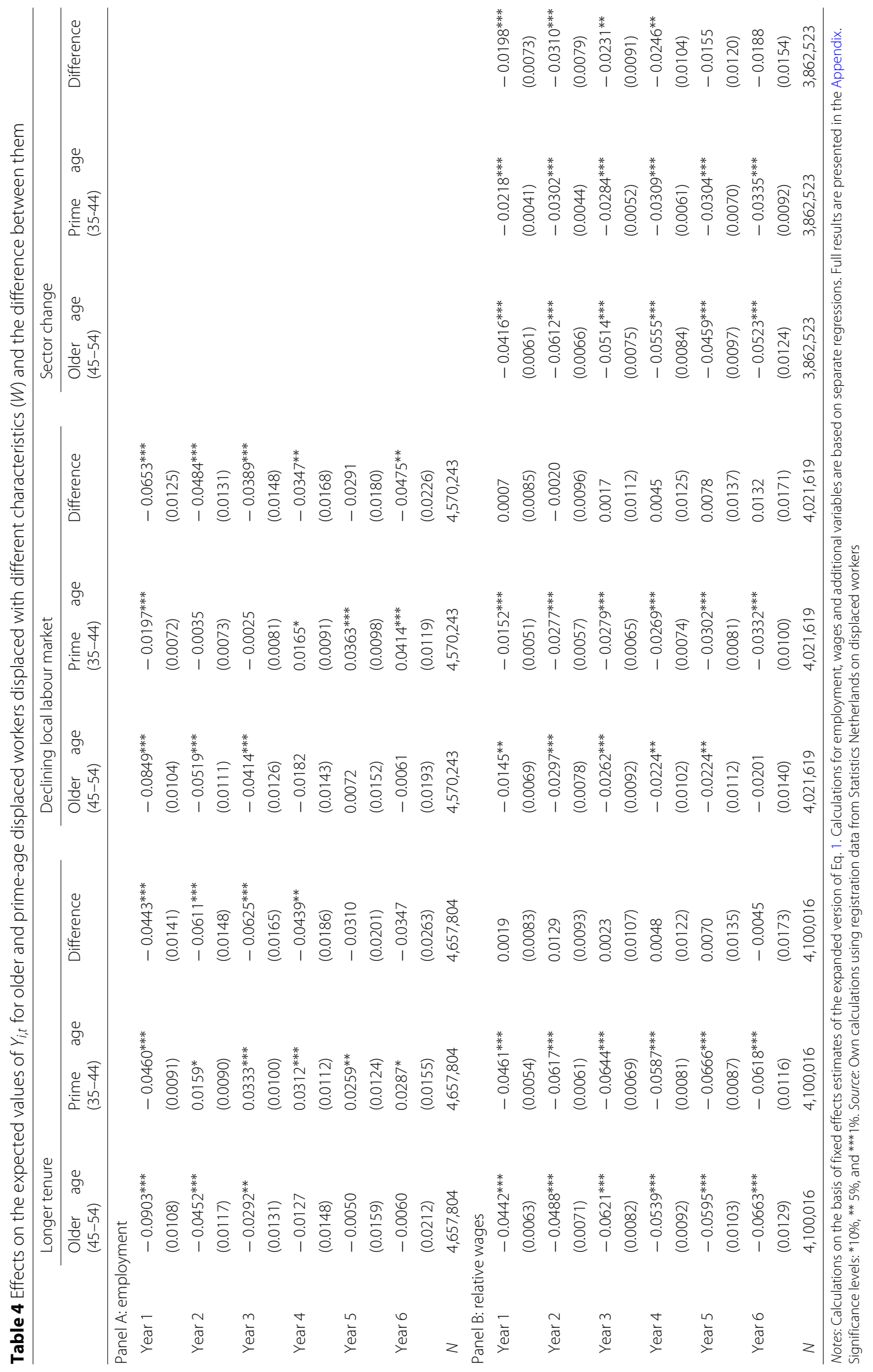


about 9 percentage point lower than for older displaced workers with short tenures. This negative effect comes down gradually in the subsequent years, remaining significant up to 3 years after displacement. For prime-age workers (column 2), the differences between long- and short-tenured workers are much smaller in the short run, and in the longer run, the effects become less significant. Hence, compared to prime-age workers, long tenures go along with an extra reduction in employment probability of 4 to 6 percentage points for older workers. The difference in the wage effect of displacement between long- and short-tenured workers is large. This holds for both older and primeage workers; the difference between the results for the two age groups is not statistically significant.

The conditions in the labour market from which older workers are displaced partly explains their labour market outcomes too. In accordance with the observation by Carrington (1993), we find that older workers are more sensitive to the local sectoral labour market from which they are displaced. If they are displaced from a declining local labour market, older workers experience a 8.5 percentage point larger loss in their employment probability in the the first year than if they are displaced from a stable or growing industry. For older workers, this difference declines to 4.1 percentage points in the third year and fades out in the longer run. The adverse impact is concentrated among older workers, since for prime-age workers, the impact is smaller and often insignificant. Finding a match in which older workers can use their (probably relatively obsolete) specific human capital may be a problem if the whole sector is declining. The estimated effect of being displaced from a declining labour market on wages is about -3 percentage points in the second year for both age groups; the effect remains persistent for several years.

Our results also support the hypothesis that older workers are more sensitive to switching industries. Older displaced workers who find new employment in a different industry than the one from which they were displaced suffer a wage loss of about 4 to 6 percentage points compared to those who found a job in the same industry. For prime-age workers, these effects are about 3 percentage points and decline over time. The results indicates that the difference between older workers and prime-age workers are large and increase over time. In general, our results suggest that job- and sector-specific factors are important for understanding the more vulnerable position of older workers after job loss.

\section{Sensitivity analyses}

We have carried out six sensitivity tests. First, we estimate our main equation separately for men and women. Table 5 shows the results for the overall displacement effects for older and prime-age men and women. It is clear that especially older men lose more in terms of employment probabilities than older women. For wages, on the other hand, the results of men and women are fairly comparable.

Second, we compare results for the period up to 2006 and the period from 2006 onwards. In 2006, Dutch labour and social security legislation changed in many respects. Not only was there a major reform of the disability system, but also a 2-year continuation of wage payments for sick workers was introduced, the health insurance system was changed, early retirement schemes were abolished, the maximum duration of unemployment benefits was shortened and employment protection changed. 


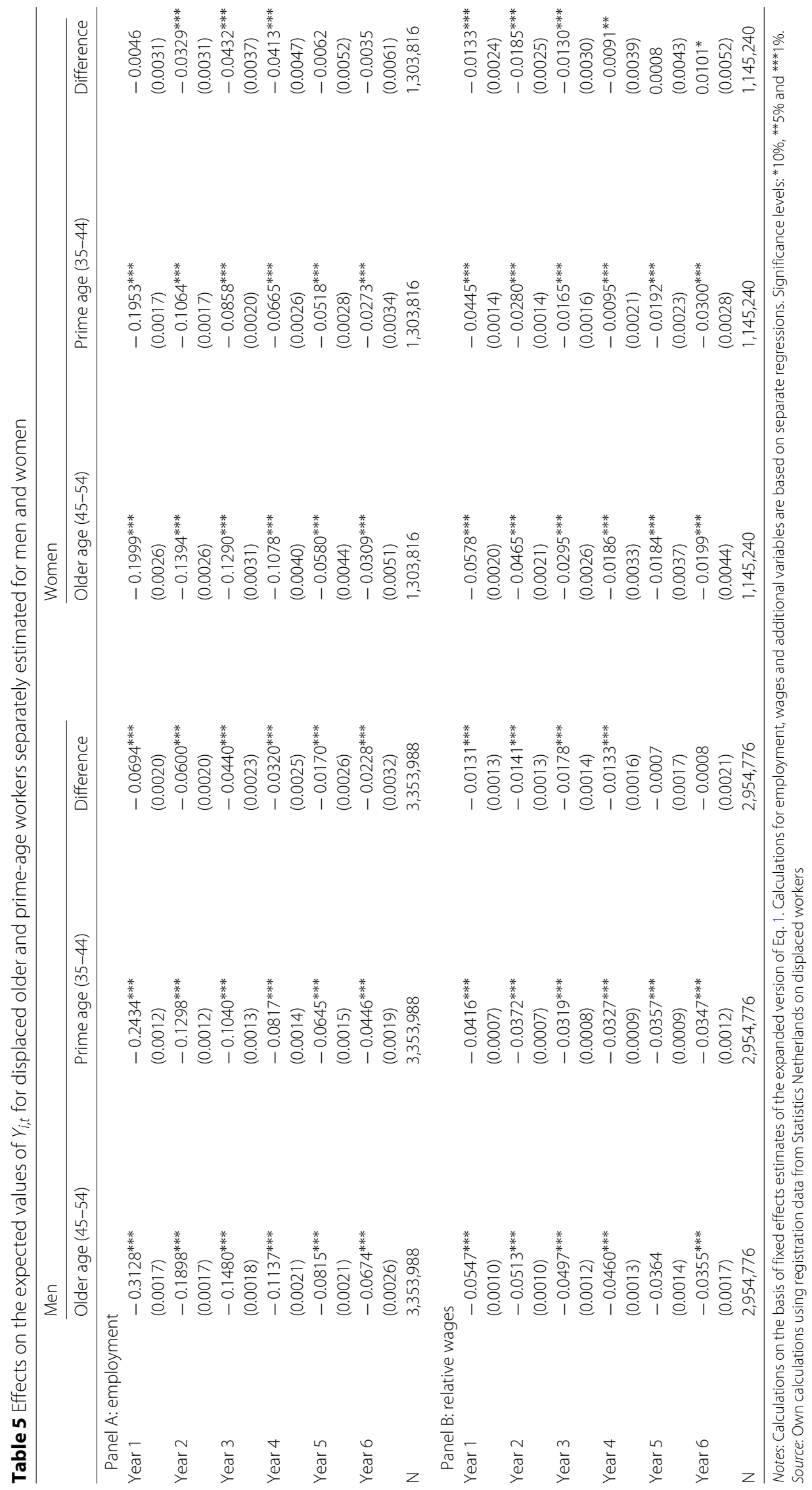


From 2006 onwards, there is no longer a pure last-in-first-out (lifo) rule in case of collective dismissal, but lifo by age group. As a result, older workers are more often displaced. The reforms in the unemployment benefits are most important for our research topic. The maximum duration was shortened, and entrance to unemployment benefits was relaxed in cases of displacement by mutual consent. For most unemployed workers, this reform reduced the period of benefit entitlement, sometimes the reduction was as strong as 22 months, although it did increase the entitlement period for some other groups by at most 2 months. Previous empirical evidence shows that this reform increased job-finding rates, but led to a decrease in the quality of the jobs found (De Groot and van der Klaauw 2014).

As a third sensitivity check, we have run our analyses, in the same specifications as above, separately for people who were displaced before 2006 and those displaced thereafter. Table 6 show the results for the overall displacement effects. The results confirm that employment probabilities of displaced workers have improved slightly after the reform, at least in the short run. We also observe that the wage reductions are larger after the reform. The interpretation of the long-run effects is less clear, since the Dutch labour market was hit by the Great Recession in 2009. This means that our results likely overestimate the actual impact of the reform on wages and underestimate the impact on employment ${ }^{23}$.

Fourthly, we test the sensitivity of our results by estimating the treatment effects separately for different education levels. Table 7 shows that higher educated workers have a slightly lower employment probability than low- and middle-educated workers. In terms of wages, the disadvantage for older workers compared to their prime-age counterparts is largest for higher educated workers, probably because they are prone to have accumulated much firm-specific human capital.

Fifthly, we have repeated the baseline analysis for the absolute wage levels instead of wages relative to the wage 13 months before displacement. Appendix: Table 9 confirms the main result that wages of older workers are more negatively affected than those of prime age workers.

Finally, individuals who return to the labour market later may differ from those returning earlier, causing the wage effects to capture the role of sample composition and duration dependence. Table 8 shows the wage effects conditional on the time it took to return to employment. The effects on relative wages of displaced older and prime-age workers for workers who found a job within 6 months are clearly smaller than for those who found a job within 18 months. This finding illustrates that the main results for wages are not dominated by composition effects. A possible interpretation is that individuals who happen to receive an attractive job offer soon after displacement experience a relatively low-wage loss, whereas individuals who search longer may face a weaker bargaining position when their unemployment insurance benefits are about to end. The differences remain persistent even after several years.

For all sensitivity checks, we also estimated the heterogeneous treatment effects in the diff-in-diffs specification and the results are in line with those presented. In addition, we have tested the robustness of our main results by running similar specifications as above with different cut-off points for age, tenure and other variables ${ }^{24}$. The overall picture arising from these tests confirms our main results: older workers labour market position is more negatively affected by displacement than that of prime-age workers, whereas 


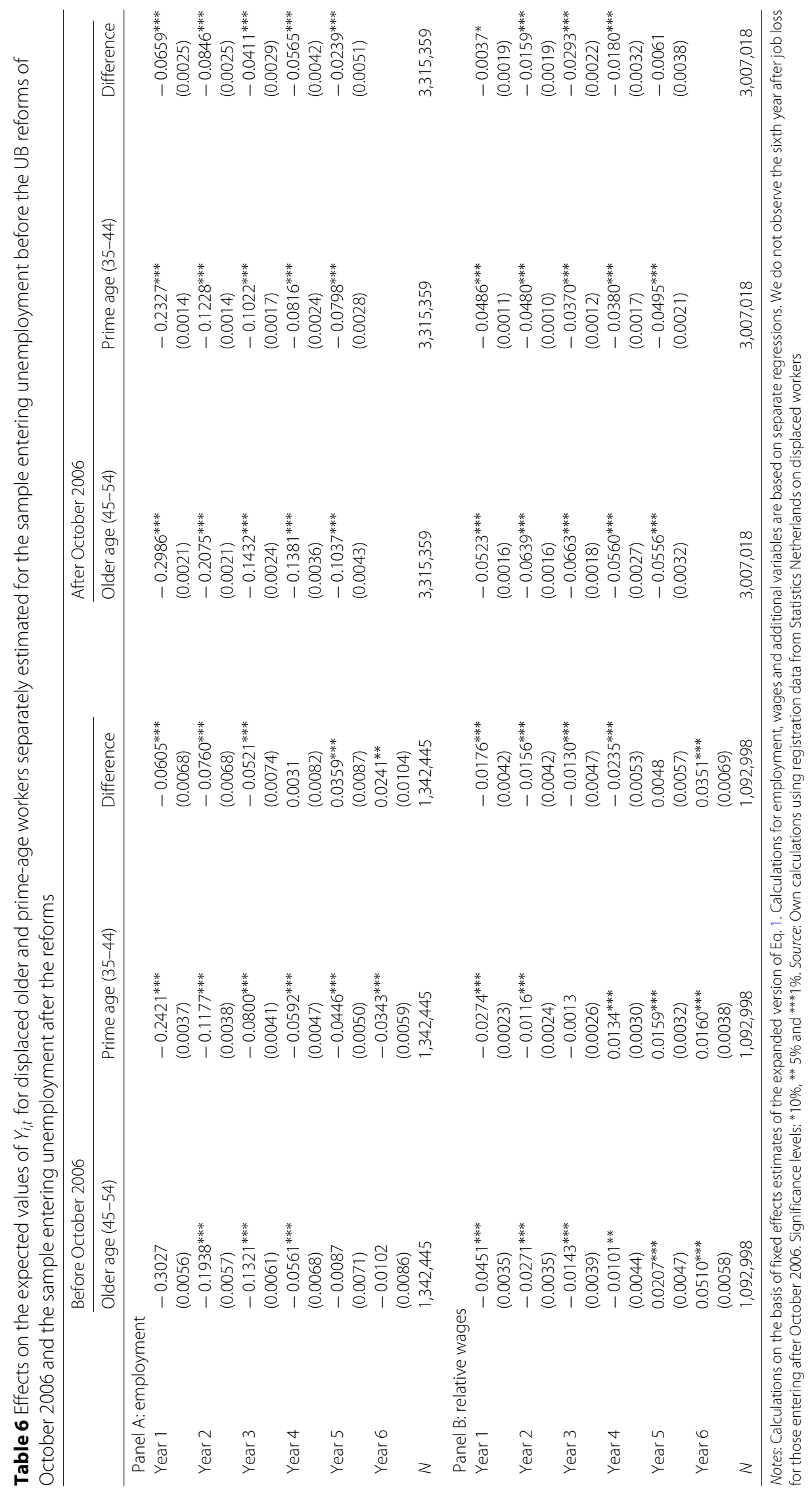




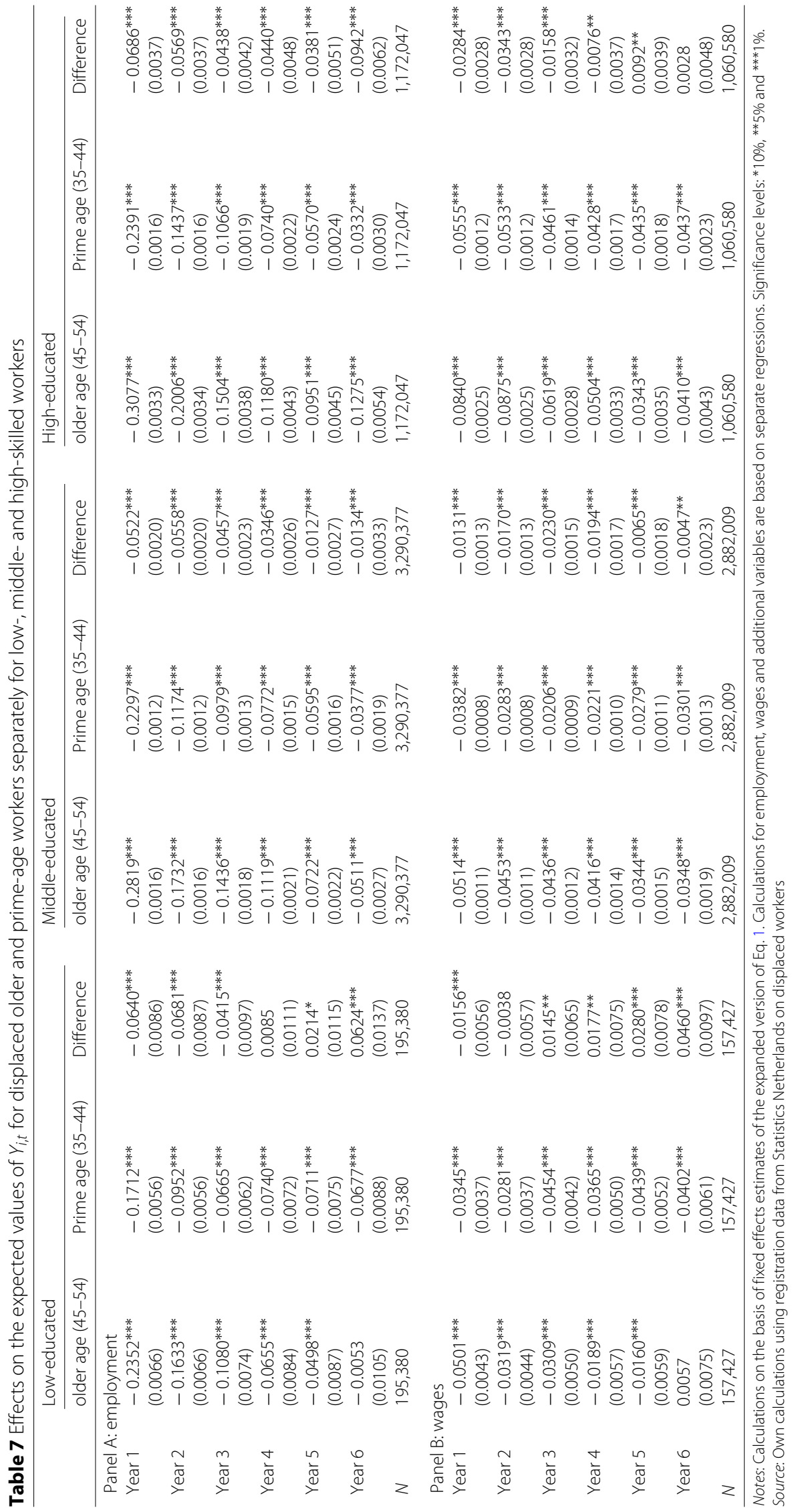




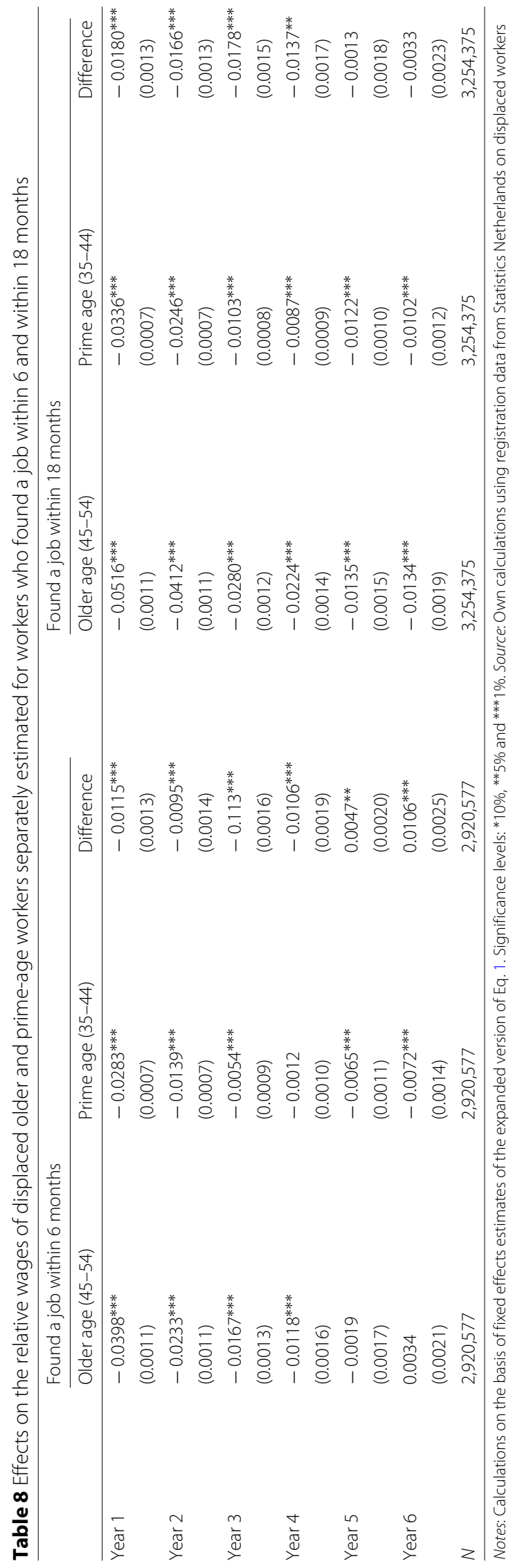


within age groups, those with longer tenure tend to be affected more, especially among the older ones.

\section{Conclusions}

This paper analysed the effect of firm bankruptcies on the employment probabilities and wages of the workers involved. Our results support the findings in the literature that displaced workers experience substantial and persistent effects on employment probabilities and wages. The size of these employment and wage effects are contingent on age. Displaced older workers face worse employment prospects than displaced prime-age workers and displaced older workers who do find a job typically experience larger wage losses than displaced prime-age workers. This picture is clear from descriptive statistics and remains after comparing the outcomes of displaced workers to a control group of workers with the same observed characteristics, who were not involved in firm bankruptcies.

Our result are probably a lower bound of the actual treatment effect, since a placebo test shows that wages start to decline more than a year before the actual job loss, while we used the 13th month before displacement as the reference point for the wage loss. Comparing to a point further in the past would likely lead to a smaller underestimation, but this would imply a restriction on the treatment and control groups regarding the employment duration before displacement. This restriction would lead to an overestimation of the actual result, since long-tenured workers suffer stronger effects.

The results clearly show heterogeneity of the displacement effect within the group of older workers. Older workers with job tenure shorter than 7 years have much better prospects than those with longer tenure. High-tenured displaced older workers experience a 5 to 9 percentage point larger drop in employment probabilities and a 4 to 5 percentage point larger decline in their relative wage in the first 2 years after displacement than short-tenured displaced older workers. This difference remains persistent for wages. For prime-age workers, tenure in the job before displacement makes less of a difference for their outcomes after displacement. In general, they have shorter tenure as well. These results suggest that factors related to long tenures (for example, accumulated firm-specific human capital, high wages due to deferred compensation schemes or strong bargaining positions of well-protected older workers) are an important explanation for the more severe consequences for older workers upon bankruptcy of their firm.

Labour market outcomes of older workers are also related to the condition of the local labour market in the industry from which they are displaced. Workers displaced from industries in which the local labour market was structurally declining have worse employment probabilities and wage prospects. In the first 2 years after displacement, employment probabilities for older workers displaced from declining industries are respectively 5 to 8 percentage points below those of older workers displaced from better performing industries, whereas wages are 2 to 3 percentage points lower, which effect persists in the long run. In general, older workers are not more often displaced from declining industries than prime-age workers, but within the group of older workers, the ones displaced from declining industries perform worse. In terms of employment outcomes, prime-age workers are less sensitive to the situation in the local labour market in the industry from which they were displaced. Our results suggest that job- and 
sector-specific factors are important for understanding the more vulnerable position of older workers after job loss.

The latter conclusion is also supported by our finding that switching industries is related to the wage effect of job loss. Older displaced workers who find new employment in a different sector than the one from which they were displaced suffer wage losses that are 4 to 6 percentage points stronger than those who find work in the same industry. This holds for prime-age workers as well, but to a lesser extent. Older workers switch to other industries almost as often as prime-age workers, but they suffer stronger wage losses after making this transition.

Theoretically, we can explain the more severe outcomes of older workers after displacement from relatively high labour costs, which result from delayed compensation schemes, higher wages due to the strong bargaining position of well-protected older workers or costly special provisions for older workers in collective bargaining schemes. The wage-toproductivity ratio of older workers might be higher due to declining productivity with age. Also, older workers' wages prior to displacement may be high because of firm-specific, industry-specific or task-specific human capital, which is lost upon displacement, causing wage drops especially in case of long job tenure and when switching industries. On the other hand, supply side arguments may play a role as well. Older workers have longer benefit entitlements, which causes higher reservation wages, and they have more options to retire from the labour market. Our results confirm that job tenure and switching industries are important, which supports the firm- and industry-specific capital argument. But a substantial part of the difference between age groups remains after controlling for these factors. This suggests that other factors may also play a role.

\section{Endnotes}

${ }^{1}$ See for example Hamermesh (1989) and Fallick (1996) for overviews. Jacobsen et al. (1993) were the first to use a comparison with non-displaced workers. Most recently, several studies by Kenneth Couch add to the US literature on displaced workers (Couch and Placzek 2010; Couch et al. 2011).

${ }^{2}$ Important examples of European studies are Burda and Mertens (2001), Kuhn (2002), Dustmann and Meghir (2005), Hijzen et al. (2010), Tatsiramos (2010), Huttunen et al. (2011) and OECD (2013).

${ }^{3}$ For example, Topel (1990), Farber (1993), Farber (1997), Couch (1998), Jacobsen et al. (1993), Eliason and Storrie (2006), Couch and Placzek (2010), OECD (2013), Ichino et al. (2013)

${ }^{4}$ In our research, we empirically define the displacement date at the time of the separation rather than the bankruptcy.

${ }^{5}$ The choice to condition on the wage 13 months before displacement instead of 12 months is motivated by the fact that monthly wages are derived from yearly wage data.

${ }^{6}$ Under the Dutch law, a debtor with at least two creditors who has ceased to pay can be declared bankrupt under the Bankruptcy Act of 1893. Bankruptcies may be filed at the request of creditors or of the firm itself and are issued by court. Firm closures not due to bankruptcies apply almost exclusively to small businesses; among larger businesses, almost all firm closures are due to bankruptcies. Unlike other collective dismissals, workers involved in a bankruptcy usually receive no compensation such as severance payments or outplacement services (Van den Berge 2016). 
${ }^{7}$ The only restriction is the fact that someone was employed the entire year before displacement and the availability of all demographic information.

${ }^{8}$ In 2006-2009, only $1.2 \%$ of workers aged 50-54 was retired (age 55-59: 6.2\%, age 60-64: 34.5\%) (http://statline.cbs.nl)

${ }^{9}$ The inflow of workers aged 45-54 in disability arrangements has come down from 33,200 persons in 2000 to 19,000 in 2004 and 10,100 in 2006 (www.uwv.nl)

${ }^{10}$ Due to the large number of potential controls relative to the number of treated, this restriction should not affect our estimates.

${ }^{11}$ Eliason and Storrie (2006); Hijzen et al. (2010) and Couch and Placzek (2010) use propensity score matching to determine the effects of job displacement.

${ }^{12}$ Education is measured in three levels: low (up to lower secondary education), middle (up to upper secondary education) and high (up to tertiary education). Working hours are measured in three groups: 0 to $18 \mathrm{~h}, 18$ to $36 \mathrm{~h}$ and $36 \mathrm{~h}$ or more. For region of residence, we take the 12 Dutch provinces. We matched exactly on those with 1-5 years of tenure, and for those with longer tenures, we matched on classes of 5 years until 30 years. Everyone with more than 30 years of tenure was included in one class.

${ }^{13}$ Since we only observe education for about two thirds of our sample and to test the sensitivity of our matching procedure, we have also applied the same procedure without education and only using wages as a proxy for education. Apart from leaving us with a larger sample, this matching procedure produces largely similar results.

${ }^{14}$ Most other studies in the large literature regarding the earnings effects of job displacement have established the sharp drop in earnings prior to job loss that was first exhibited by Jacobsen et al. (1993). Studies that do not find a dip in the wages before displacement are Couch (2001), Lengermann and Vilhuber (2002) and Schoeni and Dardia (2003). Some others (Couch and Placzek (2010) and Hildreth et al. (2007)) find upward spikes in earnings in the year prior to separation.

${ }^{15}$ Eichler and Lechner 2002 and Origo 2009, referring to techniques developed in Heckman et al. (1997), give a good overview of the issues involved.

${ }^{16}$ The structural decline in the local labour market is calculated as the moving average of the employment per region and sector given by $\Delta E=\frac{E_{t-1}+E_{t}+E_{t+1}}{E_{t-2}+E_{t-1}+E_{t}}$. We distinguish 16 sectors of industry and 12 regions (Dutch provinces).

${ }^{17}$ An implicit assumption in diff-in-diffs analyses is that there are no spillover effects or treatment externalities. This means that it is important to assure that the share of displaced workers is relatively low compared to the overall labour force. Unfortunately, we do not have data on the share of all types of dismissals per region and sector. Statistics on the inflow in unemployment benefits per municipality may however give some indication. In the first quarter of 2010, the average (weighted by the municipal labour forces) inflow in UB as a fraction of the relevant municipal labour forces was $1.5 \%$, whereas the variation was limited: in $95 \%$ of the municipalities, this fraction remained below $2.2 \%$.

${ }^{18} \mathrm{~A}$ placebo test (available upon request with the authors), with a placebo 'treatment' at 2.5 years before the actual displacement, shows that prior to displacement, the groups of treated and controls are comparable. Moving further from the placebo treatment and closer to the actual treatment, negative effects on wages are confirmed that are statistically significant.

${ }^{19} \mathrm{Keep}$ in mind that the wages of displaced workers might be biased. They might be biased upwards, because those who do find and accept a job are likely those with the 
better prospects. On the other hand, those who accept a job quickly after displacement might be the ones with low reservation wages.

${ }^{20}$ Note that already before displacement, there is a gap between older and prime-age displaced workers of approximately 0.5 percentage point (Appendix: Table 10).

${ }^{21}$ We have estimated the same specification with different cut-offs for tenure and the results are in line with those presented here.

${ }^{22}$ Since switching sectors requires having found a new job, it is impossible to estimate the 'effect' for employment probabilities.

${ }^{23}$ Note that this also partly applies to the short-run estimates for those laid off in 2008.

${ }^{24}$ The results are not reported here but are available on request.

\section{Appendix}

Full estimation results of the main specifications

Table 9 Effects on the expected values of log(wages) for displaced older and prime-age workers and the difference between them

\begin{tabular}{llll}
\hline & $\begin{array}{l}\text { Treatment effect old } \\
(45-54)\end{array}$ & $\begin{array}{l}\text { Treatment effect } \\
\text { prime-age (35-44) }\end{array}$ & $\begin{array}{l}\text { Difference between old } \\
\text { and prime-age }\end{array}$ \\
\hline Year 1 & $-0.0740^{* * *}$ & $-0.0599^{* * *}$ & $-0.0141^{* * *}$ \\
Year 2 & $(0.0010)$ & $(0.0007)$ & $(0.0012)$ \\
& $-0.0676^{* * *}$ & $-0.0497^{* * *}$ & $-0.0180^{* * *}$ \\
Year 3 & $(0.0010)$ & $(0.0007)$ & $(0.0012)$ \\
& $-0.0618^{* * *}$ & $-0.0409^{* * *}$ & $-0.0209^{* * *}$ \\
Year 4 & $(0.0012)$ & $(0.0008)$ & $(0.0014)$ \\
& $-0.0548^{* * *}$ & $-0.0392^{* * *}$ & $-0.0156^{* * *}$ \\
Year 5 & $(0.0013)$ & $(0.0009)$ & $(0.0016)$ \\
& $-0.0459^{* * *}$ & $-0.0418^{* * *}$ & $-0.0042^{* *}$ \\
Year 6 & $(0.0014)$ & $(0.0010)$ & $(0.0017)$ \\
& $-0.0432^{* * *}$ & $-0.0409^{* * *}$ & -0.0022 \\
$N$ & $(0.0017)$ & $(0.0012)$ & $(0.0021)$ \\
\hline Notes: Calculations on the basis of fixed effects estimates of Eq. 1. Significance levels: ${ }^{*} 10 \%{ }^{* *} 5 \%$ and & $4,100,016$ \\
calculations using & registration data from Statistics Netherlands on displaced workers &
\end{tabular}




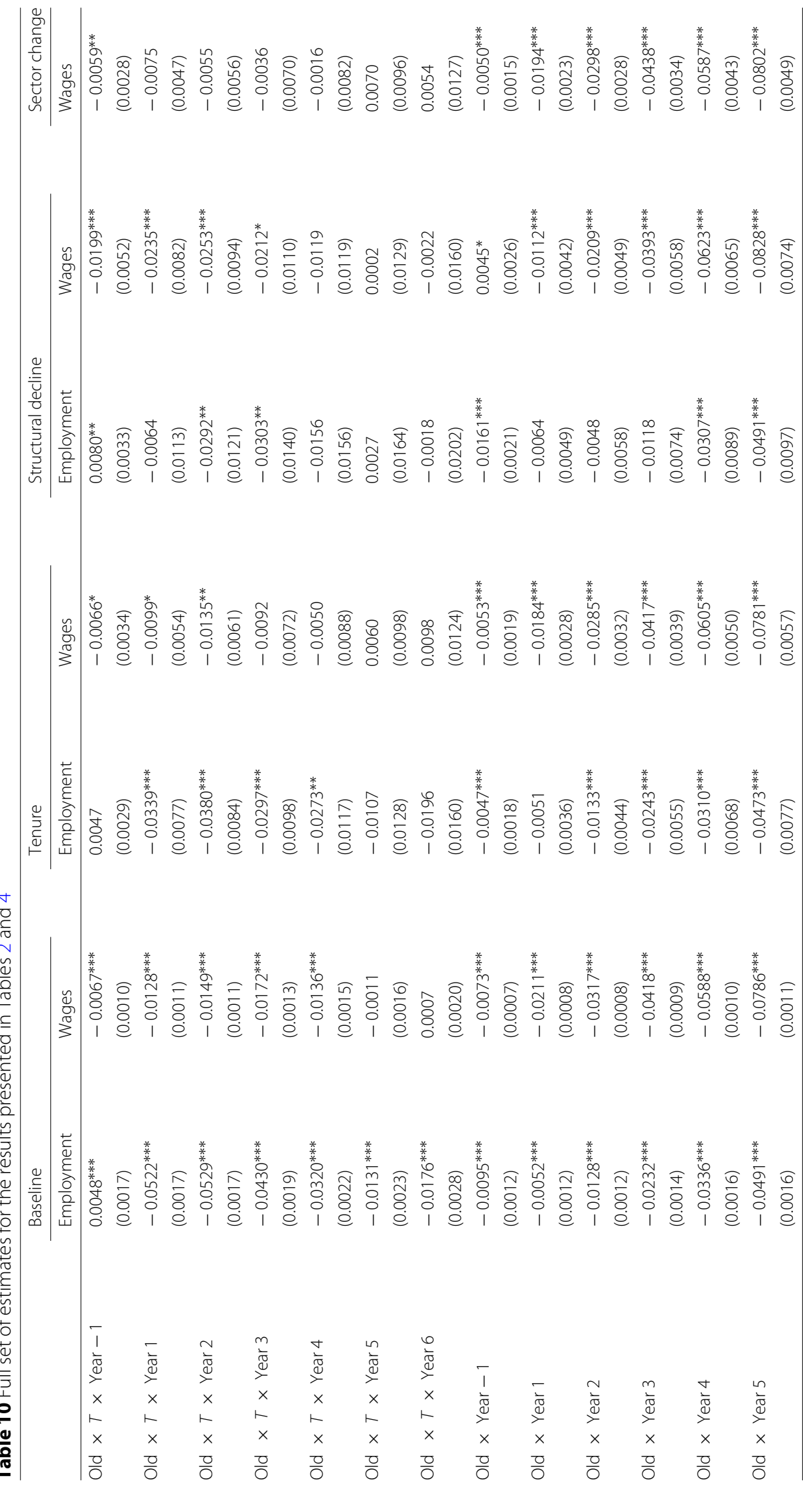




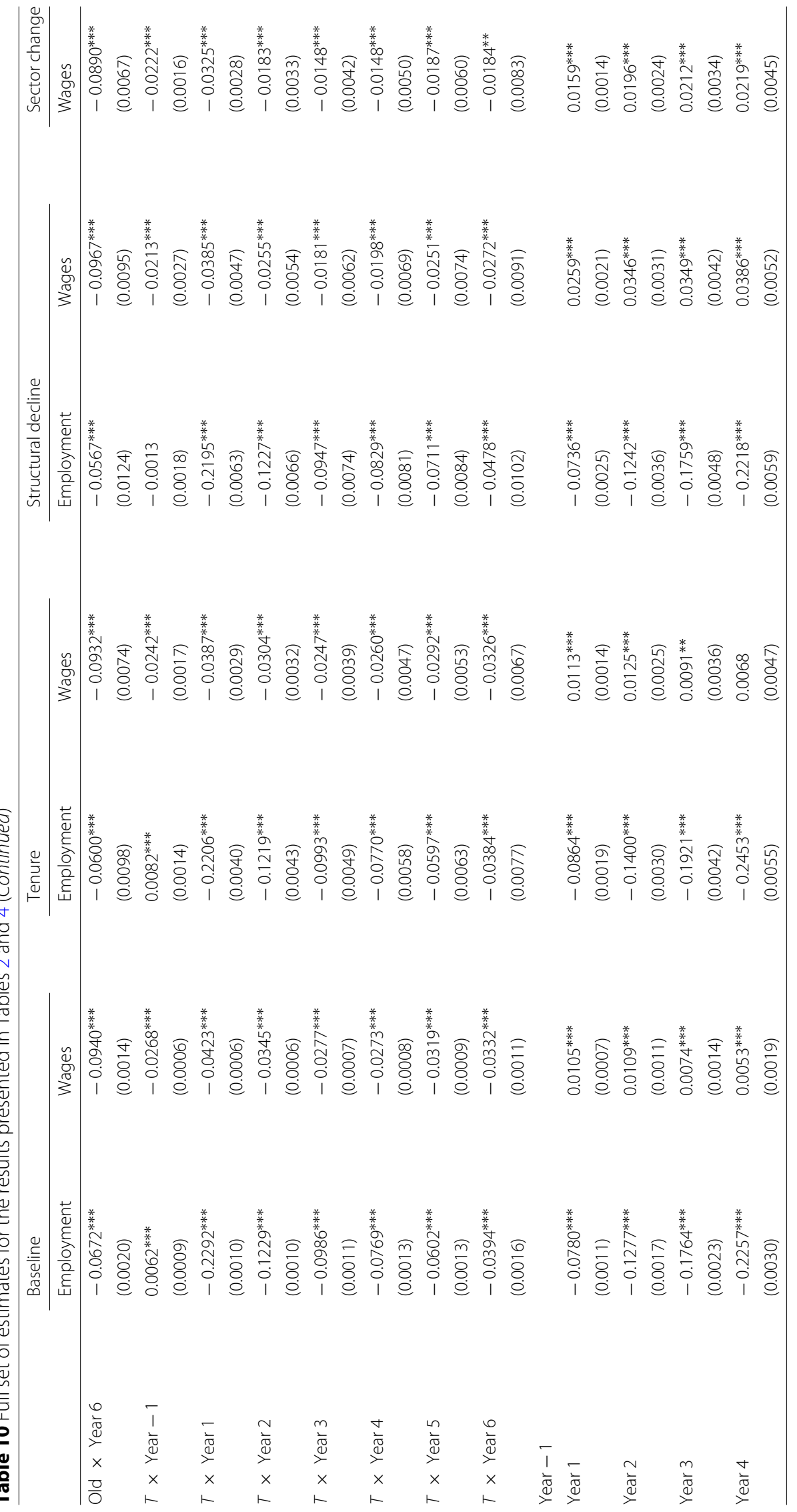




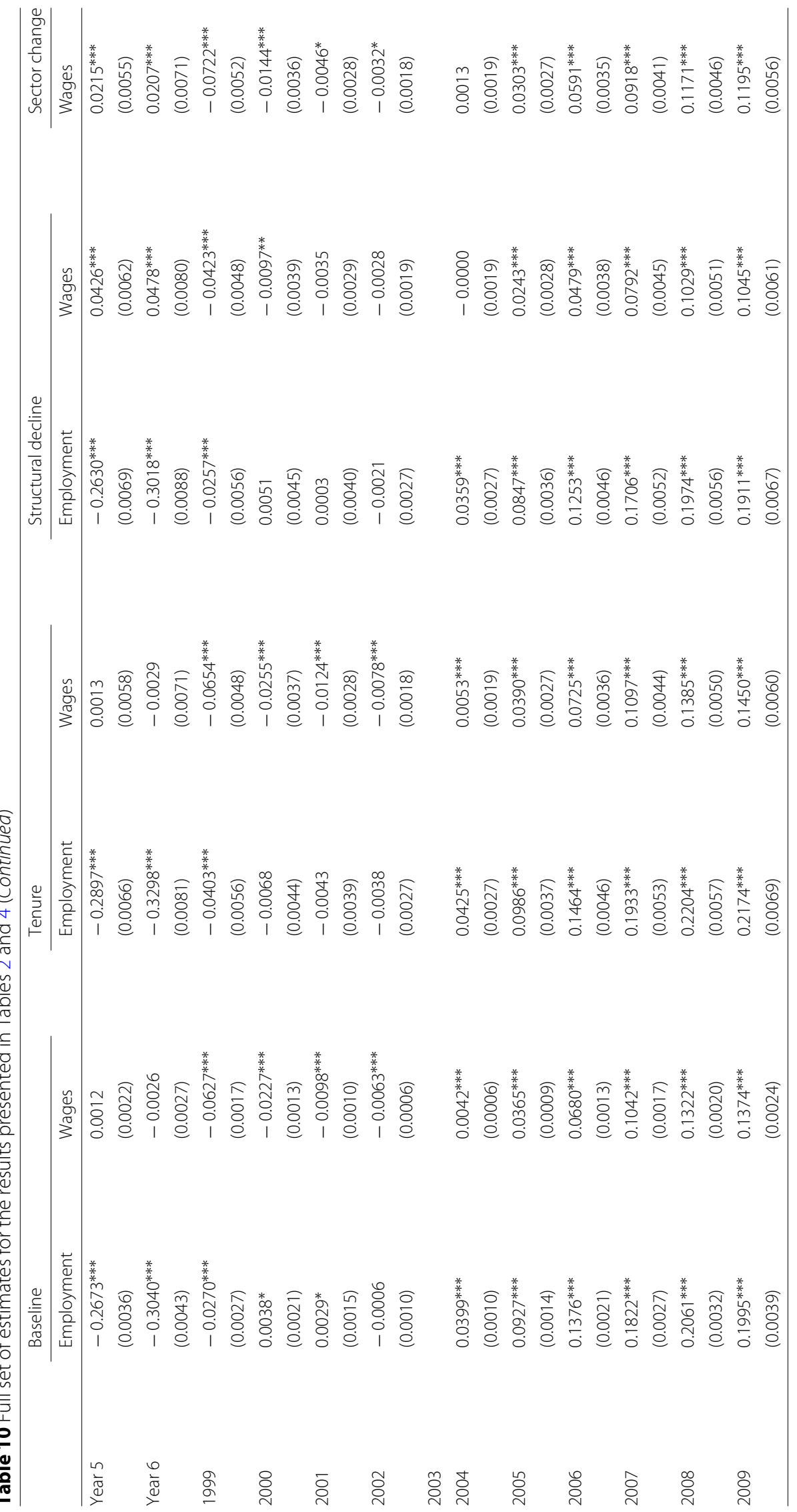




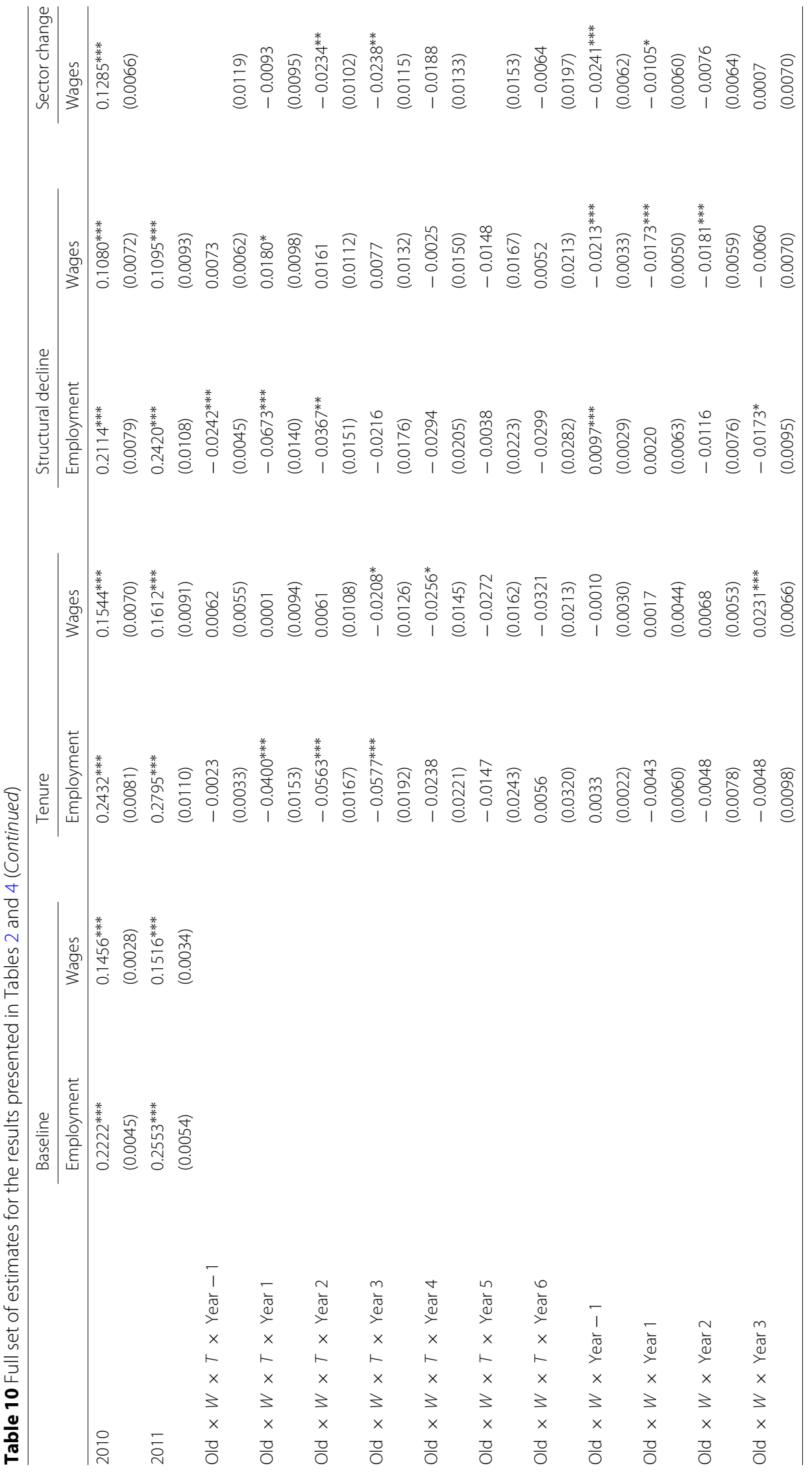




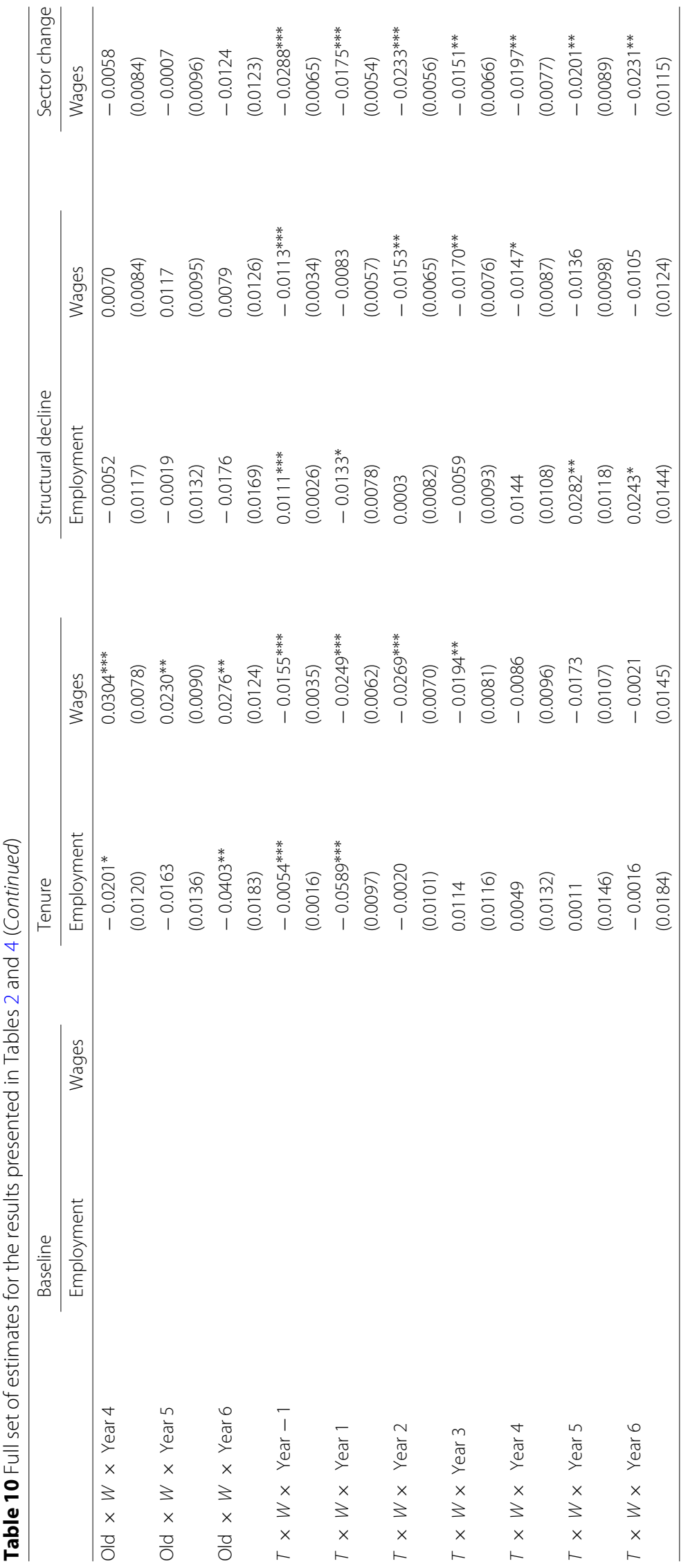




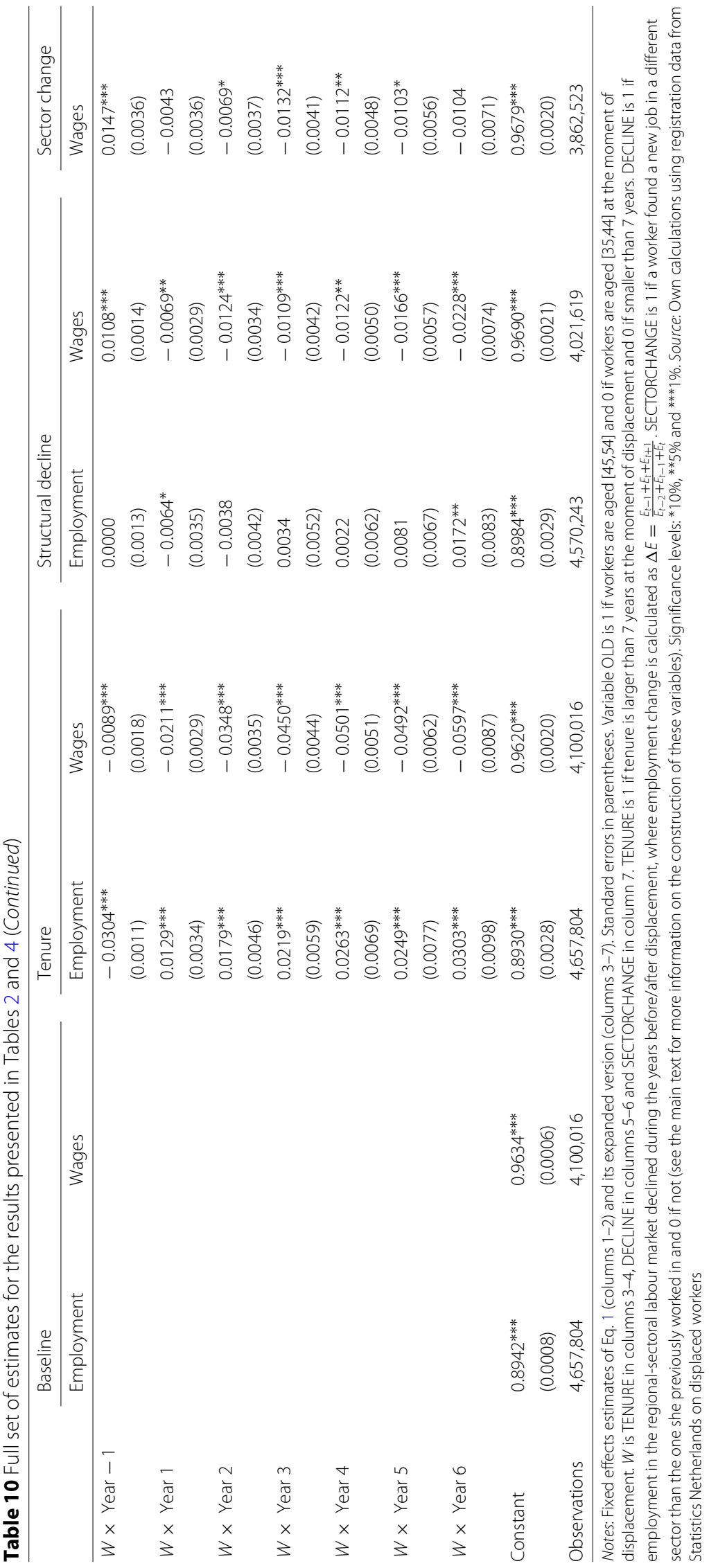




\section{Acknowledgements}

We thank Jan van Ours, Anna Salomons, Daniel van Vuuren, Bas ter Weel, the participants at the Utrecht School of Economics seminar March 2014, the seminar participants at the European Society for Population Economics 2014 conference (Braga, Portugal), the European Association of Labour Market Economists 2014 conference (Ljubljana, Slovenia) and the "Labour Market for Older Workers: Mechanisms and Institutions" conference at the Dutch Ministry of Social Affairs in 2014 for their helpful comments. We thank Adri den Ouden for the excellent research assistance. Any remaining errors are our own.

We would also like to thank the anonymous referees and the editor for the useful remarks. Responsible editor: Pierre Cahuc

\section{Funding}

This study was partially funded by the Dutch Ministry of Social Affairs and Employment.

\section{Availability of data and materials}

The paper is based on proprietary data of Statistics Netherlands. The data are only accessible through their remote access facility if a confidentiality statement has been signed. We are however able and willing to provide the programs used as well as all other details of the computations required to permit replication.

\section{Competing interests}

The IZA Journal of Labor Economics is committed to the IZA Guiding Principles of Research Integrity. The authors declare that they have observed these principles.

\section{Publisher's Note}

Springer Nature remains neutral with regard to jurisdictional claims in published maps and institutional affiliations.

\section{Received: 1 September 2017 Accepted: 12 March 2018}

Published online: 11 April 2018

\section{References}

Autor D, Dorn D (2009) This job is "getting old": measuring changes in job opportunities using occupational age structure. Am Econ Rev 99(2):45-51

Bosch N, ter Weel B (2013) Labour-market outcomes of older workers in the Netherlands: measuring job prospects using the occupational age structure. De Economist 161(2):199-218

Burda MC, Mertens A (2001) Estimating wage losses of displaced workers in Germany. Labour Econ 8(1):15-41 Carrington WJ (1993) Wage losses for displaced workers: is it really the firm that matters? J Hum Resour 28(3):435-462

Couch KA (1998) Late life job displacement. Gerontologist 38(1):7-17

Couch, KA (2001) Earnings losses and unemployment of displaced workers in Germany. Ind Labor Relat Rev 54(3):559

Couch, KA, Jolly NA, Placzek DW (2011) Earnings losses of displaced workers and the business cycle: an analysis with administrative data. Econ Lett 111(1):16-19

Couch KA, Placzek DW (2010) Earnings losses of displaced workers revisited. Am Econ Rev 100(1):572-589

Daniel K, Heywood JS (2007) The determinants of hiring older workers: UK evidence. Labour Econ 14(1):35-51

De Groot N, van der Klaauw B (2014) The effects of reducing the entitlement period to unemployment insurance benefits. IZA Discussion Paper No. 8336, Institute for the Study of Labor (IZA). (see https://ideas.repec.org/p/iza/ izadps/dp8336.html)

De Hek P, Van Vuuren D (2011) Are older workers overpaid? A literature review. Int Tax Public Financ 18(4):436-460

Dustmann C, Meghir C (2005) Wages, experience and seniority. Rev Econ Stud 72(1):77-108

Eichler M, Lechner M (2002) An evaluation of public employment programmes in the East German state of Sachsen-Anhalt. Labour Econ 9(2):143-186

Eliason M, Storrie D (2006) Lasting or latent scars? Swedish evidence on the long-term effects of job displacement. J Labor Econ 24(4):831-856

Fallick BC (1996) A review of the recent empirical literature on displaced workers. Ind Labor Relat Rev 50(1):5-16

Farber HS (1993) Brookings Papers on Economic Activity. vol. 24, issue 1 Microeconomics, $73-132$ (see https:// econpapers.repec.org/article/binbpeajo/v_3a24_3ay_3a1993_3ai_3a1993-1m_3ap_3a73-132.htm)

Farber, HS (1997) The Changing Face of Job Loss in the United States. 1981-1995 No 761, Working Papers from Princeton University, Department of Economics, Industrial Relations Section. (see https://econpapers.repec.org/paper/priindrel/ 382.htm)

Fouarge D, van Gaalen R, de Grip A (2010) Registers in sociaalwetenschappelijk onderzoek - Mogelijkheden en valkuilen, Chapter Participatie en loon na bedrijfseconomisch ontslag: Kapitaalvernietiging of negatief signaal?. CBS, The Hague. pp. 31-50

Gautier, PA, Abbring JH, van den Berg GJ, van Lomwel AGC, van Ours JC, Ruhm C (2002) Displaced workers in the United States and the Netherlands. In: Kuhn P (ed). Losing work, moving on: International perspectives on worker displacement. W.E. Upjohn Institute for Employment Research, Kalamazoo. pp 105-193

Gibbons R, Waldman M (2004) Task-specific human capital. Am Econ Rev 94(2):203-207

Hamermesh DS (1989) What do we know about worker displacement in the US? Ind Relat J Econ Soc 28(1):51-59

Heckman JJ, Ichimura H, Todd PE (1997) Matching as an econometric evaluation estimator: evidence from evaluating a job training programme. Rev Econ Stud 64(4):605-654

Heywood JS, Jirjahn U, Tsertsvardze G (2010) Hiring older workers and employing older workers: German evidence. J Popul Econ 23(2):595-615

Hijzen A, Upward R, Wright PW (2010) The income losses of displaced workers. J Hum Resour 45(1):243-269

Hildreth AKG, von Wachter TM, Handwerker EW (2007) Earnings losses of displaced workers in Connecticut. Technical report. Connecticut Department of Labor 
Huttunen K, Møen J, Salvanes KG (2011) How destructive is creative destruction? Effects of job loss on job mobility, withdrawal and income. J Eur Econ Assoc 9(5):840-870

Huynh KP, Ostrovsky Y, Petrunia RJ, Voia MC (2017) Industry shutdown rates and permanent layoffs: evidence from firm-worker matched data. IZA J Labor Econ 6(1):7

Ichino A, Schwerdt G, Winter-Ebmer R, Zweimüller J (2013) Too old to work, too young to retire? CESifo Working Paper Series 2118, CESifo Group Munich. (see https://ideas.repec.org/p/ces/ceswps/_2118.html)

Jacobsen LS, LaLonde RJ, Sullivan DG (1993) Earnings losses of displaced workers. Am Econ Rev 83(4):685-709

Kuhn PJ (ed) (2002) Losing work, moving on: international perspectives on worker displacement. W.E. Upjohn Institute for Employment Research, Kalamazoo

Lazear EP (1981) Agency, earnings profiles, productivity, and hours restrictions. Am Econ Rev 71(4):606-620

Lengermann PA, Vilhuber L (2002) Abandoning the sinking ship: the composition of worker flows prior to displacement. Longitudinal Employer-Household Dynamics Technical Papers 2002-11, Center for Economic Studies, U.S. Census Bureau. (see https://ideas.repec.org/p/cen/tpaper/2002-11.html)

Mooi-Reci I, Ganzeboom HB (2015) Unemployment scarring by gender: human capital depreciation or stigmatization? Longitudinal evidence from the Netherlands, 1980-2000. Soc Sci Res 52:642-658

Neal D (1995) Industry-specific human capital: Evidence from displaced workers. J Labor Econ 13(4):653-677

OECD (2013) Employment outlook 2013. Technical report. OECD Publishing, Paris

Origo F (2009) Flexible pay, firm performance and the role of unions. New evidence from Italy. Labour Econ 16(1):64-78

Poletaev M, Robinson C (2008) Human capital specificity: evidence from the dictionary of occupational titles and displaced worker surveys, 1984-2000. J Labor Econ 26(3):387-420

Quintin E, Stevens JJ (2005) Growing old together: firm survival and employee turnover. B.E. J Macroecon, De Gruyter 5(1):1-32. (see https://ideas.repec.org/e/pqu11.html)

Schoeni RF, Dardia M (2003) Estimates of earnings losses of displaced workers using California administrative data. Technical report. PSC Population Studies Center

Tatsiramos K (2010) Job displacement and the transitions to re-employment and early retirement for non-employed older workers. Eur Econ Rev 54(4):517-535

Topel R (1990) Specific capital and unemployment: measuring the costs and consequences of job loss. Carnegie Rochester Conf Ser Pub Policy 33(0):181-214

Van den Berge W (2016) How do severance pay and job search assistance jointly affect unemployment duration and job quality? CPB Discussion Paper 334, CPB Netherlands Bureau for Economic Policy Analysis. (see https://ideas.repec. org/p/cpb/discus/334.html)

Van Ours JC, Vodopivec M (2006) How shortening the potential duration of unemployment benefits affects the duration of unemployment: evidence from a natural experiment. J Labor Econ 24(2):351-378

\section{Submit your manuscript to a SpringerOpen ${ }^{\odot}$ journal and benefit from:}

- Convenient online submission

- Rigorous peer review

- Open access: articles freely available online

- High visibility within the field

- Retaining the copyright to your article

Submit your next manuscript at $\downarrow$ springeropen.com 